\title{
EFFECT OF SOLAR RADIATION AND MULCHING MATERIALS ON WET AND DRY SOIL HEATING
}

\author{
Derbala, $A *$ and M. Darwesh $* *$
}

\section{ABSTRACT}

This study aimed to investigate the effect of solar radiation on soil temperature in the case of using different materials named organic mulching (rice straw and bare soil) and inorganic ones (black and colourless plastic mulches). The difference between upper and lowersurface mulch element temperature is measured under these materials. Regression analysis between net radiation flux incident on each mulch material and temperature differences show that high significant occurred with black, colourless plastic and rice straw mulching materials. Also, bare soil after irrigation appeared the same trend. In general, the coefficient of determination $\left(R^{2}\right)$ ranged between 0.51 and 0.80 with black plastic, 0.50 and 0.88 with colourless plastic, 0.50 and 0.89 with rice straw mulch, 0.62 and 0.81 with bare soil. The mulching materials arranged according to the net solar radiation flux incident on each mulch material in order: $R_{n}$, black $>R_{n}$, wet bare soil $>R n$, dry bare soil $>R_{n}$, rice straw and $R_{n}$, white plastic.

\section{INTRODUCTION}

$\mathrm{M}$ ulching technique is widely used to moderate soil microclimatic conditions. These microclimatic factors strongly affect soil temperature and soil moisture in the root zone, which, in turn, may influence plant growth and productivity. Many researchers have shown that the temperature and moisture aspects of mulching can enhance the phenology yield and quality of certain crops. (Kar, 2003; Singh et al., 2007; Rong Li et al., 2013) Others have demonstrated that the quality of radiation reflected from certain mulches can have a direct effect on aboveground plant growth or deter the immigration of disease-carrying insects (Greenough et al. 1990).

\footnotetext{
*Associate Prof., of Agric. Eng. Dept., Fac. of Agric., Tanta Univ.
} ** Lec. of Agric. Eng. Dept., Fac. of Agric., Tanta Univ. 
Horowitz et al. (1983) used a solarization technique as a method of heating the soil by using polyethylene sheets as mulching over moistened soil, to retain radiation from sun during the hot season. While, Lamont (1993), revealed that, the soil temperature in the planting bed is raised, promoting faster crop development and earlier harvest. Mulching decreases the fluctuations in temperature in the first 20-30 cm depth in soils and promotes root development, reduce fertilizer leaching and soil compaction, and the vegetable productions are cleaner since no soil is splashed onto the plants or fruits Ham et al., (1993). The effects of mulching on soil microclimate are largely controlled by both radiation regimes and turbulent transfer within the mulch. Many different materials are used as a mulching material. These materials may from synthetic mulches or organic mulches. One important component of plastic culture is plastic mulches that have been used commercially for the production of vegetables. Al-Karaghouli et al. (1990) and Kluitenberg et al., (1991) showed that the color of polyethylene sheets which used for soil mulching is an important parameter in governing the capturing solar insolation. In addition, plastic mulches affect the field microclimate by modifying the radiation budget of the surface and suppressing soil water evaporation. Mulches materials may transmit, absorb, or reflect a portion of the incident radiation at each wavelength, plastic mulch may transmit almost all the radiation at one wavelength, while strongly absorbing or reflecting radiation another. Additionally, one must consider shortwave originating from the sun $(0.2$ to $1.2 \mu \mathrm{m})$ and long wave originating from terrestrial sources $(2$ to $50 \mu \mathrm{m})$. Thus, predicting how a given plastic will influence the field environment requires a complete spectral characterization of the material in the shortwave and longwave band. The color of the mulch is largely determined its energy radiation behavior and its influence on the microenvironment surrounding the plants. The soil temperature under a plastic mulch depends on the thermal properties (reflectivity, absorptivity, or transmissivity) of a particular material according to the incoming solar radiation. Another type of mulching material is crop residues which conserve soil and modify soil microclimate when left on the surface as a 
mulch material Unger, (1994). Wheat hay and rice straw is widely used as a mulching materials. In Egypt, rice straw is normally burnt prior to sowing the following crop and this operation is a major source of air pollution. To avoid the burning operation of rice straw, it residues can be used it on the soil surface as a mulching material. Therefore, the objectives of this research work are study the influence solar radiation flux incident and different coloured polyethylene and rice straw mulches on soil temperature, soil moisture content and fresh yield characteristics.

\section{MATERIALS AND METHODS}

\section{Site and climate}

The experiments were carried out at the Faculty of Agriculture farming, Tanta University, Gharbia governorate, (latitude $30.825^{\circ} \mathrm{N}$, longitude $30.994^{\circ} \mathrm{E}$ and altitude $8.5 \mathrm{~m}$ above mean sea level) during June, (2012). Based on earlier recommendations in the region, seeds of cowpea were planted on $3^{\text {rd }}$ of May, 2012. The climate of the study area is semi-arid with no rainfall during experiment period.

\section{Soil mulching}

Mulching treatments were comprised of colorless polyethylene (CP) 100$\mu \mathrm{m}$ thick, black polyethylene (BP) $100 \mu \mathrm{m}$ thick. polyethylene sheets have two dimensions $0.25 \times 0.40 \times 10 \mathrm{~m}$ and $0.25 \times 0.80 \times 10 \mathrm{~m}$ while rice straw (RS) at the rate 2 t.ha $^{-1}$ and bare soil (BS) as a control unit. The soil of the experiments site is silty clay loam, which constituted of $16 \%$ sand, $40 \%$ silt and $44 \%$ clay

\section{Experimental design and crop management}

The cowpea was grown according to the ridge and furrow methods of planting with spacing into two categories $0.40 \mathrm{~m}$ (half- mulching) and $0.80 \mathrm{~m}$ (full mulching). The irrigation treatments formed the main plots and mulching and non-mulching were subplot of the experimental randomized block with three replicates. Each treatment was carried out in triplicate as listed in Table (1). Three irrigation treatments $\left(I_{1}, I_{2}\right.$ and $\left.I_{3}\right)$ were $I_{1}$ : before irrigation, $I_{2}$ : between irrigation and $I_{3}$ : after irrigation, 46 $\mathrm{mm}$ water was applied each irrigation and plots were bordered to prevent runoff. 
Table 1. Layout of experimental field.

\begin{tabular}{||c|c|c|c|c||}
\hline \hline TREATMENTS & $\mathrm{CP}$ & $\mathrm{BP}$ & $\mathrm{RS}$ & $\mathrm{BS}$ \\
\hline \multirow{3}{*}{$\mathrm{I}_{1}$} & $\mathrm{R}_{1}$ & $\mathrm{R}_{1}$ & $\mathrm{R}_{1}$ & $\mathrm{R}_{1}$ \\
\cline { 2 - 5 } & $\mathrm{R}_{2}$ & $\mathrm{R}_{2}$ & $\mathrm{R}_{2}$ & $\mathrm{R}_{2}$ \\
\cline { 2 - 5 } & $\mathrm{R}_{3}$ & $\mathrm{R}_{3}$ & $\mathrm{R}_{3}$ & $\mathrm{R}_{3}$ \\
\hline \multirow{3}{*}{$\mathrm{I}_{2}$} & $\mathrm{R}_{1}$ & $\mathrm{R}_{1}$ & $\mathrm{R}_{1}$ & $\mathrm{R}_{1}$ \\
\cline { 2 - 5 } & $\mathrm{R}_{2}$ & $\mathrm{R}_{2}$ & $\mathrm{R}_{2}$ & $\mathrm{R}_{2}$ \\
\cline { 2 - 5 } & $\mathrm{R}_{3}$ & $\mathrm{R}_{3}$ & $\mathrm{R}_{3}$ & $\mathrm{R}_{3}$ \\
\hline \multirow{3}{*}{$\mathrm{I}_{3}$} & $\mathrm{R}_{1}$ & $\mathrm{R}_{1}$ & $\mathrm{R}_{1}$ & $\mathrm{R}_{1}$ \\
\cline { 2 - 5 } & $\mathrm{R}_{2}$ & $\mathrm{R}_{2}$ & $\mathrm{R}_{2}$ & $\mathrm{R}_{2}$ \\
\cline { 2 - 5 } & $\mathrm{R}_{3}$ & $\mathrm{R}_{3}$ & $\mathrm{R}_{3}$ & $\mathrm{R}_{3}$ \\
\hline
\end{tabular}

CP: colorless plastic mulching sheet, BP: black plastic mulching sheet, RS: rice straw mulching material, BS: bare soil;

\section{Solar radiation flux incident horizontal surface}

The horizontal plane of the ground surface continually receives two components of solar radiation; beam solar radiation $\left(I_{D}\right)$ in $\mathrm{W} / \mathrm{m}^{2}$, and diffuse solar radiation $\left(I_{d}\right)$ in $\mathrm{W} / \mathrm{m}^{2}$. To compute the hourly average total solar radiation flux incident on a horizontal surface $\left(I_{T}\right)$ in $\mathrm{W} / \mathrm{m}^{2}$, the following equations were functioned (ASHRAE, 2005):

$$
, \quad I_{T}=I_{D H}+I_{d} \mathrm{~W} / \mathrm{m}^{2}
$$

\section{Direct total solar radiation $\left(\mathbf{I}_{\mathrm{DH}}\right)$}

$$
I_{D H}=I_{D N} \times \cos (\theta), \mathrm{W} / \mathrm{m}^{2} .
$$

Where, $\left(\mathrm{ID}_{\mathrm{H}}\right)$ is the direct total solar radiation flux incident on a horizontal surface, $\left(\mathrm{ID}_{\mathrm{N}}\right)$ is direct normal solar radiation and the cosine of incidence $(\theta)$ between the incoming solar rays and a line perpendicular to the surface. But, in horizontal plane case the tilt angle equal zero, consequently, $\cos \left(\theta_{\mathrm{H}}\right)=\sin (\psi)$. Therefore, the direct solar radiation on its surface, $\mathrm{I}_{\mathrm{DH}}$, is thus equal

$I_{D H}=I_{D N} \times \sin (\psi), \mathrm{W} / \mathrm{m}^{2}$

Where, $\sin (\psi)$ is sine solar altitude angle.

Solar irradiance $\left(\mathrm{I}_{\mathrm{DN}}\right)$ can be calculated by the following equation:

$$
I_{D N}=\frac{A}{\exp \left[\frac{B}{\sin \psi}\right]}, \mathrm{W} / \mathrm{m}^{2}
$$


Where, A, apparent solar irradiation at air mass $=0$ in $\mathrm{W} / \mathrm{m}^{2}$ and $\mathrm{B}=$ atmospheric extinction coefficient in decimal.

\section{Diffuse solar radiation from a clear sky $\left(I_{d}\right)$}

A simplified general relation for the diffuse solar radiation $\left(I_{d}\right)$ in $W / m^{2}$ from a clear sky that falls on a horizontal surface is:

$I_{d}=C I_{D H}$

Where, C, diffuse solar radiation factor, $C I_{D H}$ is sky solar radiation falling on a horizontal surface.

The apparent solar radiation (A), atmospheric extinction coefficient (B), and the diffuse solar radiation factor $(\mathrm{C})$ are listed in Table (2).

Table (2): Number of the day (n), declination angle $(\delta)$, apparent solar radiation (A), atmospheric extinction coefficient (B), and diffuse solar radiation factor $(C)$ for the average day June month (ASHRAE, 2005):

\begin{tabular}{|l||l|l|l|l|l|l||}
\hline Month & Date & $\mathrm{n}$ & $\delta$ & $\mathrm{A}$ & $\mathrm{B}$ & $\mathrm{C}$ \\
\hline \hline June & 11 & 162 & 23.1 & 1095 & 0.185 & 0.137 \\
\hline
\end{tabular}

Therefore, the hourly average total solar radiation incident on the ground surface is computed by:

$$
I_{T}=I_{D H} \sin (\psi)+C I_{D H}, \mathrm{~W} / \mathrm{m}^{2}
$$

Consequently, can be written eq. (5) as follows:

$$
I_{T}=I_{D H}(C+\sin \psi), \mathrm{W} / \mathrm{m}^{2} \text {. }
$$

The net shortwave radiation $\left(\mathrm{R}_{\mathrm{n}}\right)$ resulting from the balance between incoming and reflected solar radiation according to Raes (2009) is given by:

$\mathrm{R}_{\mathrm{n}}=(1-\alpha) I_{T}, \mathrm{~W} / \mathrm{m}^{2}$

Where, $\mathrm{R}_{\mathrm{n}}$ is net solar or shortwave radiation in $\mathrm{W} / \mathrm{m}^{2}, \alpha$ is albedo for the reference surface, decimal

Lists albedo values of several surfaces including black, white plastic mulch; rice straw as mulching material; wet and dry silty clay soil as showing in Table (3) 
Table (3):Albedo of various surfaces according Tarara (2000) and Adel (2002)

\begin{tabular}{||l|l|l|l|l|l||}
\hline \hline SURFACE & BLACK & WHITE & RICE & DRY & WET \\
& PLASTIC & PLASTIC & STRAW & SOIL & SOIL \\
\hline Albedo & 0.03 & 0.48 & 0.40 & 0.23 & 0.15 \\
\hline
\end{tabular}

-Temperature indicators

To judge for mulching process the upper and lower temperature difference may gave an indicator for different mulching materials. This criterion can be used for comparing various types of elements of mulch. The equations by Novak et al. (2000) as follows:

$$
\Delta \mathrm{T}_{\text {upper }}=\mathrm{T}_{\mathrm{u}-\mathrm{T}_{\mathrm{a}}}
$$

Where, $\Delta \mathrm{T}_{\text {upper }}$ is temperature difference upper mulch in ${ }^{\circ} \mathrm{C}, \mathrm{T}_{\mathrm{u}}$ is uppersurface mulch -element temperature in ${ }^{\circ} \mathrm{C}$ and $\mathrm{T}_{\mathrm{a}}=$ air temperature in ${ }^{\circ} \mathrm{C}$ $\Delta \mathrm{T}_{\text {lower }}=\mathrm{T}_{\mathrm{d}}-\mathrm{T}_{\mathrm{a}}$

Where, $\mathrm{T}_{\mathrm{d}}=$ lower- surface mulch -element temperature in ${ }^{\circ} \mathrm{C}$.

\section{Instrumentation}

A 24 therimstors were located in the plots to measure the temperature above and under mulching layer. Two therimstors were also, placed to measure the air temperature. These therimstors were connected to four data loggers of 8 channels. The means of 60 scans were automatically recorded every hour, and the data thereafter transferred into a computer file during the experimental work.

\section{RESULTS AND DISCUSSION}

Net radiation $\left(R_{n}\right)$ values, indicated that the largest day-time energy input, it's the sum of all radiation exchange at the surface of a plant $\left(R_{n}\right.$, canopy), soil ( $\mathrm{R}_{\mathrm{n}}$, soil), or mulch $\left(\mathrm{R}_{\mathrm{n}}\right.$, mulch) its composed of solar short wave [(sw), 0.2 to $1.4 \mu \mathrm{m})]$ and terrestrial long wave [(Lw, 2 to $50 \mu \mathrm{m})$ ] radiation. Pohotosynthetically active radiation comprises the $0.4-0.7 \mu \mathrm{m}$ waveband; solar energy above $0.7 \mu \mathrm{m}$ is referred to as "near- infrared" radiation. Global irradiance $\left(\mathrm{I}_{\mathrm{T}}\right)$ pointed to the total of direct and diffuse solar radiation. Both solar and terrestrial radiation are absorbed, reflected, and transmitted in various proportions according to the optical properties of a surface: absorptance, reflectance and transmittance. Thereby, resulting in optical properties of mulch surface the behavior of different mulching materials may describe how can be warmed of soil. 
Fig (1) indicates the relationship between solar radiation and local standard time on 11 June, which represents the average day for June month. The different types of solar radiation flux incident on the horizontal mulching surfaces increased gradually with solar day time from sunrise until they reach the maximum amounts at noon and the minimum at sunset. The highest absorbed solar radiation $\left(\mathrm{I}_{\mathrm{T}}\right)$ was recorded in the case of using black polyethylene as mulching material while the one with white plastic, for other mulching material they lied in between. Fig(1) also shows that black plastic mulch and bare soil could have higher $R_{n}$ values. At first glance, one might expect $R_{n}$, black mulch to exceed $R_{n}$, soil because the black plastic absorbed $96 \%$ of $I_{T}$ while the bare soil absorbed only 77\%. Net radiation differed by $80 \mathrm{~W} / \mathrm{m}^{2}$ near midday when the soil surface was dry. When the bare soil surface was wet its shortwave absorptance increased because a wet soil is darker than a dry one. Thereto, rice straw absorbed $60 \%$ from $\mathrm{I}_{\mathrm{T}}$, while white plastic mulch absorbed $52 \%$ from $\mathrm{I}_{\mathrm{T}}$. Therefore, $\mathrm{R}_{\mathrm{n}}$, rice straw was higher than $\mathrm{R}_{\mathrm{n}}$, white plastic mulch.

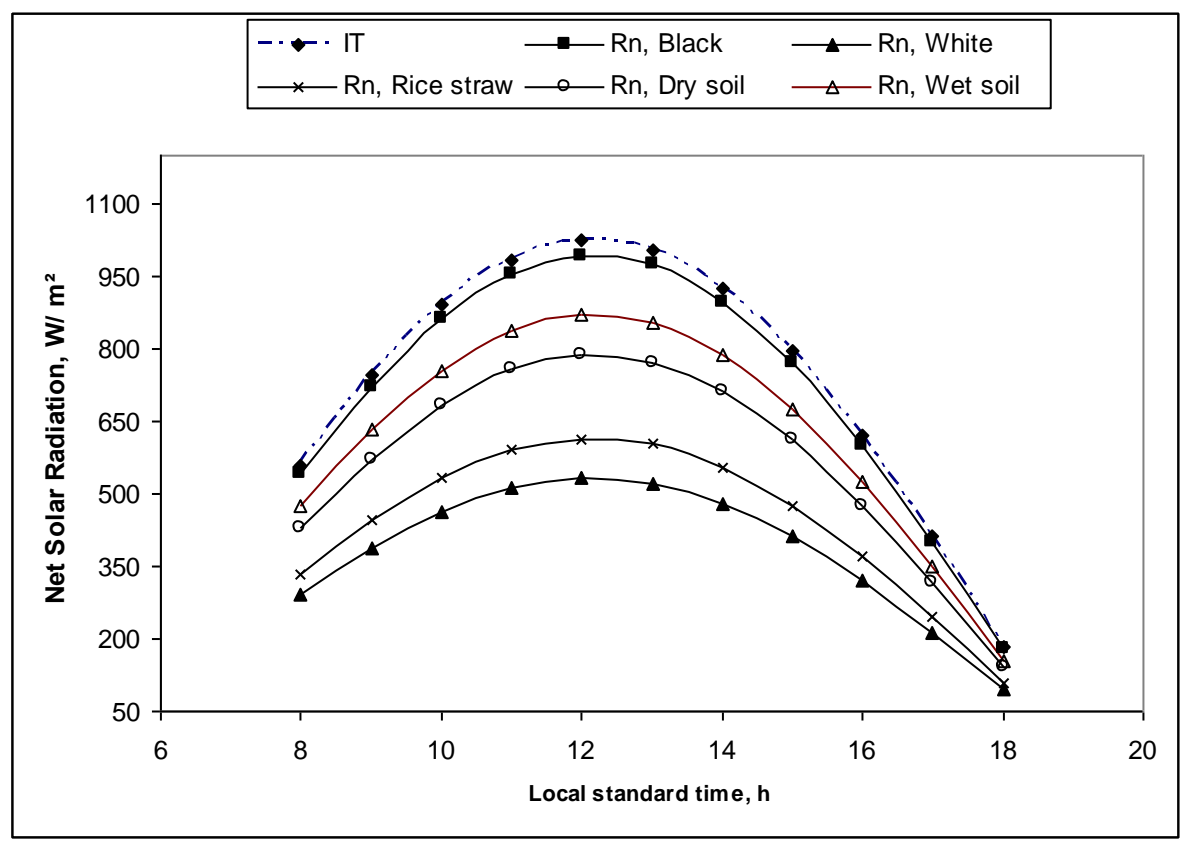

Fig.(1): Hourly average absorbed solar radiation and net solar radiation of mulch element type and local standard time. 
The relationship between upper, lower surface temperature differences and the net radiation flux incident above the mulch during the daytime, as shown, Figs. 2, 3 and 4. $T_{u}-T_{a}$ at the top and $T_{d}-T_{a}$ of the mulch plotted versus $R_{n}$ above and under the mulch. Generally, $T_{u}-T_{a}$ is near to negative values in the start day and then, increasing to reach a positive values to sunset. The big difference of upper and lower temperatures, when using black plastic sheet after irrigation and in between irrigation for both 40 and $80 \mathrm{~cm}$ bed width line. The upper surface difference temperatures ranged from -10 to $22{ }^{\circ} \mathrm{C}$ at beginning day and noon of day, respectively. While the lower surface difference temperature ranged from -6 to $17{ }^{\circ} \mathrm{C}$ at beginning and end of the day. Also, the lower difference temperatures less than the upper difference temperatures. Meanwhile, before irrigation the upper and lower surfaces difference temperature is very low, compared to other irrigation treatments. Figs. 2, 3 and 4, also, indicated that a negative values between temperature differences and solar radiation flux incident on mulch element especially at sunrise and sunset time. The positive values appeared when values of solar radiation increased especially at noontime (midday). The highest temperature differences appeared in Figs. 3 and 4 that represents after and in between irrigation. This mean that the treatments of irrigation affect in these values. Fig. 2. illustrate that upper and lower difference temperature had low values ranged from -11 to -1 ${ }^{\circ} \mathrm{C}$, at sunrise and sunset time because these times had lower solar radiation values, adversely noon time. Another reason cause the decreased values was the soil before irrigation. Nevertheless, upper difference temperature had high values in beginning and finishing day ranged from 1 to $0{ }^{\circ} \mathrm{C}$ because the soil was irrigated. In addition, the temperature differences values were lower in between irrigation treatments than after irrigation. The data not present any evidence about relation between bed width line and heating the soil, this mean that no significant of bed width on mulching process. Figs. 2,3and 4 showed that hourly averages temperature difference at upper surface were higher than lower surface in all treatments, this refer to transmissitivity of solar radiation above the mulch element and ability of this radiation to penetrate the soil underlying mulch element to heat the soil. 


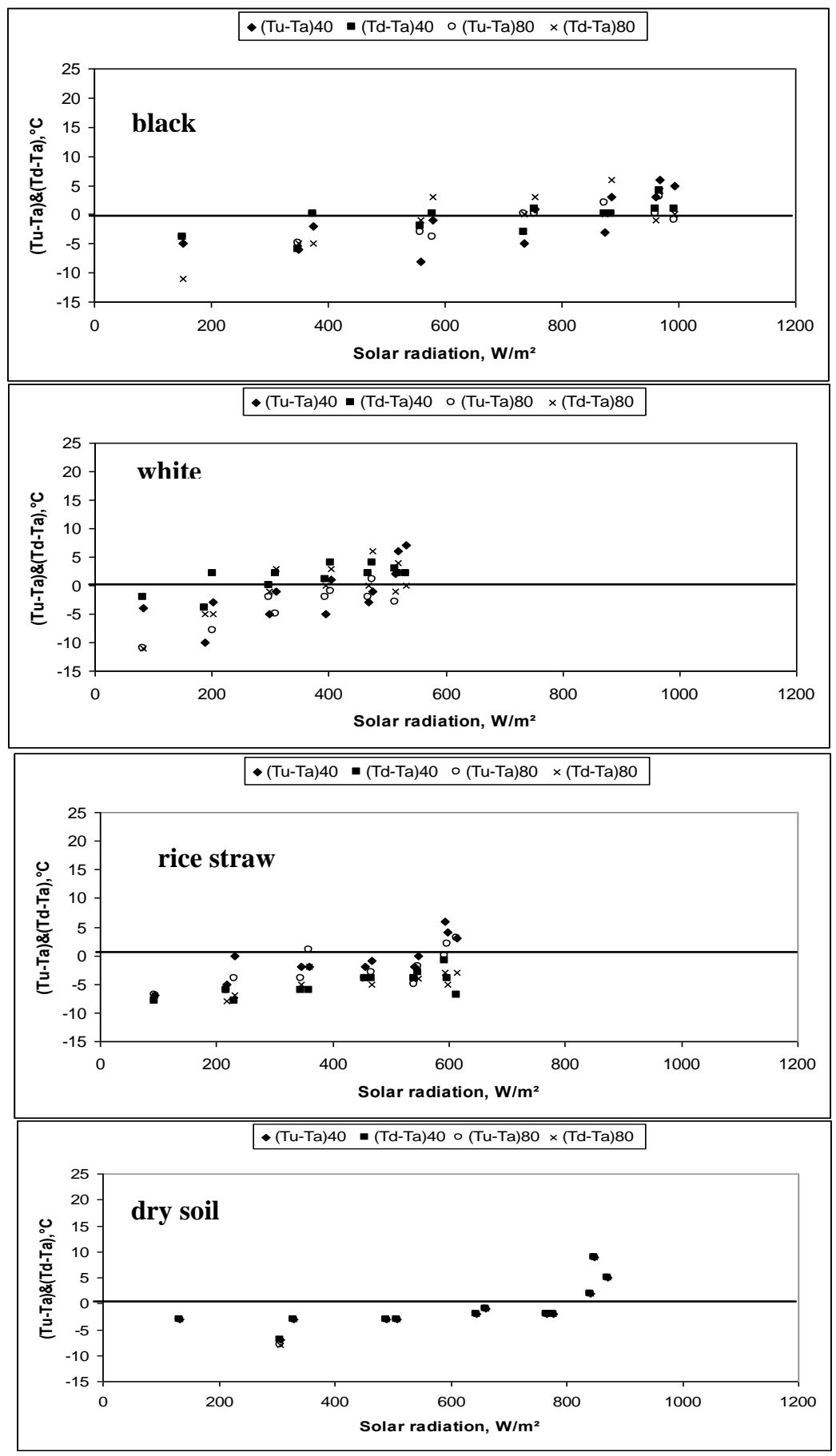

(a)

(b)

(c)

(d)

Fig.(2) :Difference between hourly average lower-surface, $T_{d}$, or upper surface $T_{u}$, mulch element temperature and ambient air temperature $T_{a}$ vs the net radiation flux incident above the mulch during $9: 00 \mathrm{am}$ to 18:00 pm on 6 June before irrigation 


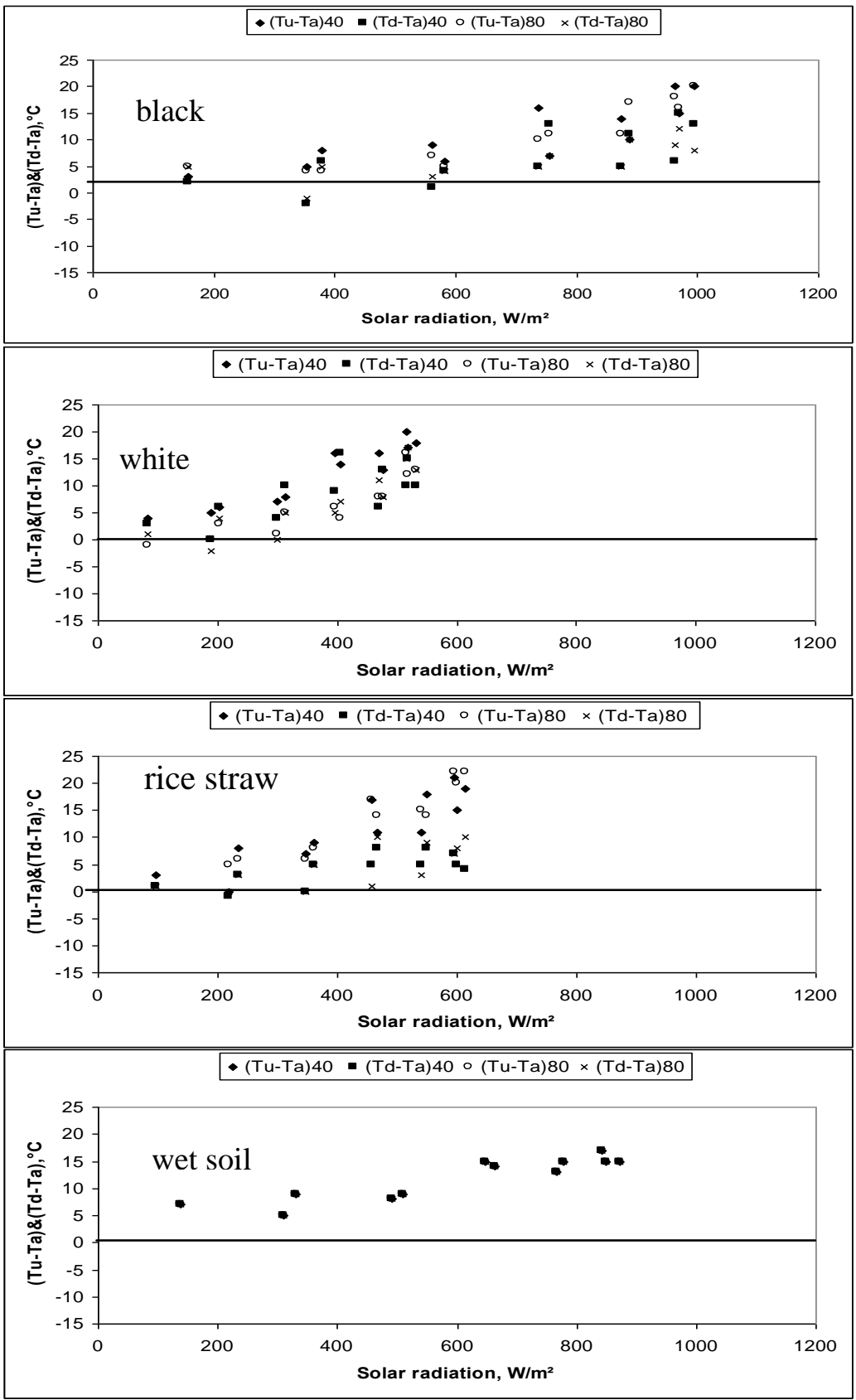

(a)

(b)

(c)

(d)

Fig.(3): Difference between hourly average lower-surface, $\mathrm{T}_{\mathrm{d}}$, or upper surface $T_{u}$, mulch element temperature and ambient air temperature $T_{a}$ vs the net radiation flux incident above the mulch during $9: 00$ am to 18:00 pm on 12 June after irrigation 


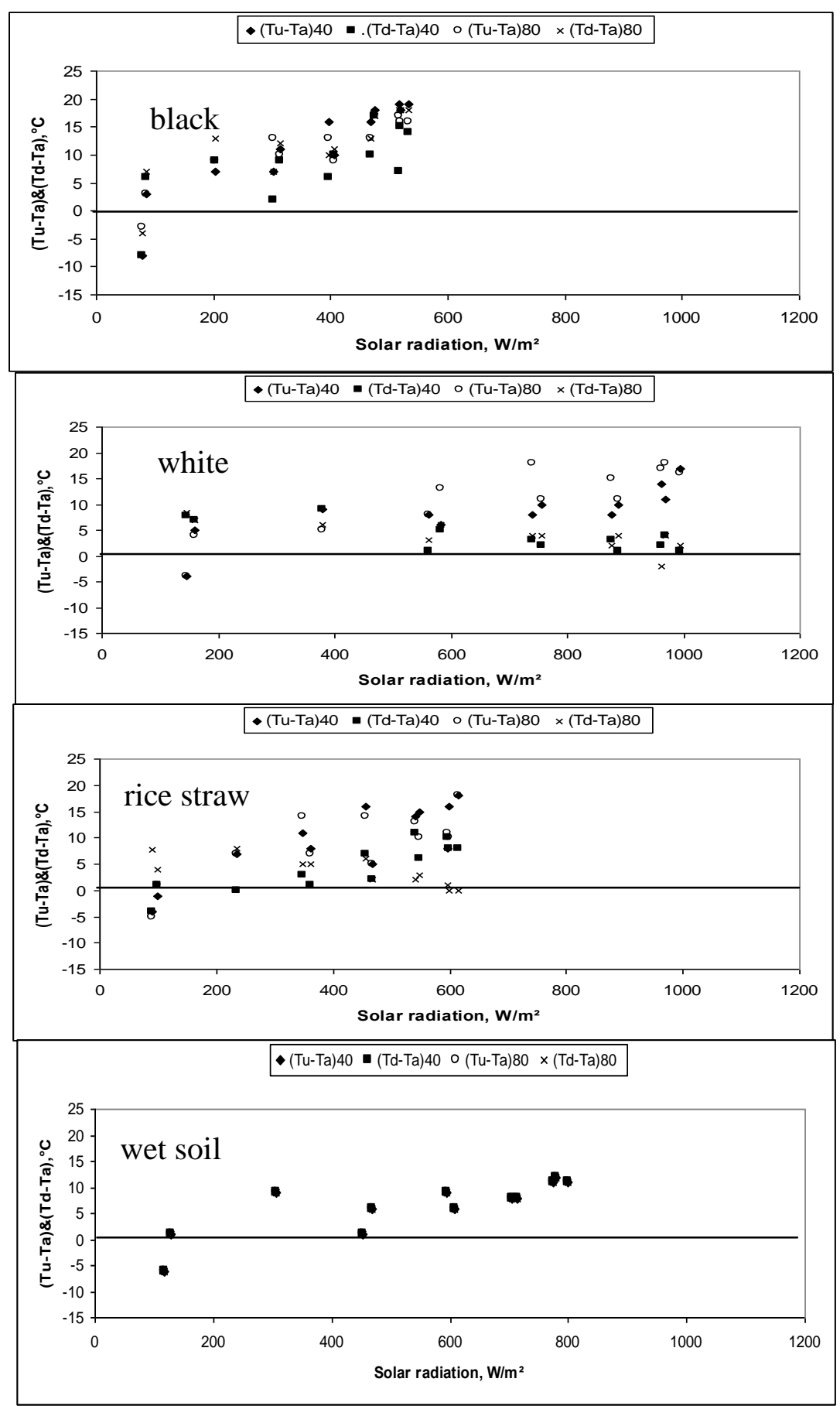

(a)

(b)

(c)

(d)

Fig.(4). Difference between hourly average lower-surface, $T_{d}$, or upper surface

$T_{u}$, mulch element temperature and ambient air temperature $T_{a}$ vs the net radiation flux incident above the mulch during $9: 00$ am to 18:00 pm on 24 June in between irrigation 
Tables (4), (5) and (6) indicated the regression relationship between $\Delta \mathrm{T}$ upper, lower mulch element and net solar radiation during all irrigation treatments in this experiment. The regression equations evident that the slope was positive values in all irrigation treatments. This means that when solar radiation increased both of upper and lower differences also increased. Except upper difference temperature when using black plastic sheet the slope was negative values especially at 40 and $80 \mathrm{~cm}$ bed width line, the same result explicit at

Table (4).Regression analysis and significance (before irrigation)

\begin{tabular}{|c|c|c|}
\hline Color & $\begin{array}{l}\text { Linear regression of lower } \\
\text { temperature difference }\end{array}$ & $\begin{array}{l}\text { Linear regression of upper } \\
\text { temperature difference }\end{array}$ \\
\hline Black & $\begin{array}{l}\Delta \mathrm{T}_{40}=0.0121 \mathrm{R}_{\mathrm{n}}-9.229 \\
\mathrm{R}^{2}=0.5354 \quad * * \\
\Delta \mathrm{T}_{80}=0.0064 \mathrm{Rn}-5.3873 \\
\mathrm{R}^{2}=0.5193 \quad * *\end{array}$ & $\begin{array}{l}\Delta \mathrm{T}_{40}=0.007 \mathrm{R}_{\mathrm{n}}-5.4627 \\
\mathrm{R}^{2}=0.5364 * * \\
\Delta \mathrm{T}_{80}=0.0131 \mathrm{R}_{\mathrm{n}}-9.4879 \\
\mathrm{R}^{2}=0.6088 \quad * *\end{array}$ \\
\hline White & $\begin{array}{l}\Delta \mathrm{T}_{40}=0.0231 \mathrm{R}_{\mathrm{n}}-9.7709 \\
\mathrm{R}^{2}=0.5128 \\
\Delta \mathrm{T}_{80}=0.0227 \mathrm{R}_{\mathrm{n}}-11.041 \\
\mathrm{R}^{2}=0.75\end{array}$ & $\begin{array}{l}\Delta \mathrm{T}_{40}=0.0112 \mathrm{R}_{\mathrm{n}}-2.7709 \\
\mathrm{R}^{2}=0.5094 * * \\
\Delta \mathrm{T}_{80}=0.0244 \mathrm{R}_{\mathrm{n}}-9.4879 \\
\mathrm{R}^{2}=0.6088 \quad * *\end{array}$ \\
\hline Rice straw & $\begin{array}{l}\Delta \mathrm{T}_{40}=0.0171 \mathrm{R}_{\mathrm{n}}-7.8658 \\
\mathrm{R}^{2}=0.64 \quad * * \\
\Delta \mathrm{T}_{80}=0.0133 \mathrm{R}_{\mathrm{n}}-8.0382 \\
\mathrm{R}^{2}=0.50 \\
* *\end{array}$ & $\begin{array}{l}\Delta \mathrm{T}_{40}=0.0087 \mathrm{R}_{\mathrm{n}}-8.7388 \\
\mathrm{R}^{2}=0.50 \quad * \\
\Delta \mathrm{T}_{80}=0.0067 \mathrm{R}_{\mathrm{n}}-7.9402 \\
\mathrm{R}^{2}=0.515 \quad * *\end{array}$ \\
\hline Dry soil & $\begin{array}{l}\Delta \mathrm{T}_{40,80}=0.0176 \mathrm{R}_{\mathrm{n}}-3.1154 \\
\mathrm{R}^{2}=0.6266 \quad * *\end{array}$ & $\begin{array}{l}\Delta \mathrm{T}_{40}, 80=0.0176 \mathrm{R}_{\mathrm{n}}-3.1154 \\
\mathrm{R}^{2}=0.6266 \quad * *\end{array}$ \\
\hline
\end{tabular}

Table (5). Regression analysis and significance (after irrigation treatment)

\begin{tabular}{|c|c|c|}
\hline Color & $\begin{array}{l}\text { Linear regression of lower } \\
\text { temperature difference }\end{array}$ & $\begin{array}{l}\text { Linear regression of upper } \\
\text { temperature difference }\end{array}$ \\
\hline Black & $\begin{array}{l}\Delta \mathrm{T}_{40}=0.0173 \mathrm{R}_{\mathrm{n}}-0.7647 \\
\mathrm{R}^{2}=0.6266 \quad * * * \\
\Delta \mathrm{T}_{80}=0.019 \mathrm{Rn}-2.3059 \\
\mathrm{R}^{2}=0.8077 \quad \text { *** }\end{array}$ & $\begin{array}{l}\Delta \mathrm{T}_{40}=0.0137 \mathrm{R}_{\mathrm{n}}-2.7733 \\
\mathrm{R}^{2}=0.5091 \\
\Delta \mathrm{T}_{80}=0.0089 \mathrm{R}_{\mathrm{n}}-0.0796 \\
\mathrm{R}^{2}=0.6088\end{array}$ \\
\hline White & $\begin{array}{l}\Delta \mathrm{T}_{40}=0.0357 \mathrm{R}_{\mathrm{n}}-1.1144 \\
\mathrm{R}^{2}=0.8833 * * * \\
\Delta \mathrm{T}_{80}=0.0322 \mathrm{R}_{\mathrm{n}}-5.5618 \\
\mathrm{R}^{2}=0.7975 \quad * * *\end{array}$ & $\begin{array}{l}\Delta \mathrm{T}_{40}=0.0234 \mathrm{R}_{\mathrm{n}}-0.0761 \\
\mathrm{R}^{2}=0.5049 \quad * * \\
\Delta \mathrm{T}_{80}=0.0351 \mathrm{R}_{\mathrm{n}}-5.8618 \\
\mathrm{R}^{2}=0.7477 \quad * * *\end{array}$ \\
\hline Rice straw & $\begin{array}{l}\Delta \mathrm{T}_{40}=0.0336 \mathrm{R}_{\mathrm{n}}-2.6525 \\
\mathrm{R}^{2}=0.7714 * * * \\
\Delta \mathrm{T}_{80}=0.0394 \mathrm{R}_{\mathrm{n}}-4.1873 \\
\mathrm{R}^{2}=0.8973 \quad * * *\end{array}$ & $\begin{array}{l}\Delta \mathrm{T}_{40}=0.0122 \mathrm{R}_{\mathrm{n}}-1.0022 \\
\mathrm{R}^{2}=0.50 \quad * * \\
\Delta \mathrm{T}_{80}=0.0163 \mathrm{R}_{\mathrm{n}}-2.1411 \\
\mathrm{R}^{2}=0.5103 \quad * *\end{array}$ \\
\hline Wet soil & $\begin{array}{l}\Delta \mathrm{T}_{40,80}=0.01486 \mathrm{R}_{\mathrm{n}}+2.985 \\
\mathrm{R}^{2}=0.815 \quad \text { *** }\end{array}$ & $\begin{array}{l}\Delta \mathrm{T}_{40,80}=0.01486 \mathrm{R}_{\mathrm{n}}+2.985 \\
\mathrm{R}^{2}=0.815 \quad \text { *** }\end{array}$ \\
\hline
\end{tabular}


Table (6).Regression analysis and significance( in between irrigation)

\begin{tabular}{|c|c|c|}
\hline Color & $\begin{array}{l}\text { Linear regression of lower } \\
\text { temperature difference }\end{array}$ & $\begin{array}{l}\text { Linear regression of upper } \\
\text { temperature difference }\end{array}$ \\
\hline Black & $\begin{array}{l}\Delta \mathrm{T}_{40}=0.0136 \mathrm{R}_{\mathrm{n}}-0.8547 \\
\mathrm{R}^{2}=0.6545 \quad * * \\
\Delta \mathrm{T}_{80}=0.01979 \mathrm{Rn}-2.1414 \\
\mathrm{R}^{2}=0.8077 \quad * * *\end{array}$ & $\begin{array}{l}\Delta \mathrm{T}_{40}=-0.00074 \mathrm{R}_{\mathrm{n}}+8.86 \\
\mathrm{R}^{2}=0.5091 \\
\Delta \mathrm{T}_{80}=-0.0067 \mathrm{R}_{\mathrm{n}}+8.506 \\
\mathrm{R}^{2}=0.6218 \quad * *\end{array}$ \\
\hline White & $\begin{array}{l}\Delta \mathrm{T}_{40}=0.0465 \mathrm{R}_{\mathrm{n}}-5.3256 \\
\mathrm{R}^{2}=0.8682 \\
\Delta \mathrm{T}_{80}=0.0336 \mathrm{R}_{\mathrm{n}}-0.9653 \\
\mathrm{R}^{2}=0.8259 \quad * * *\end{array}$ & $\begin{array}{l}\Delta \mathrm{T}_{40}=0.0289 \mathrm{R}_{\mathrm{n}}-2.2683 \\
\mathrm{R}^{2}=0.5150 \quad * * \\
\Delta \mathrm{T}_{80}=0.0324 \mathrm{R}_{\mathrm{n}}-0.0648 \\
\mathrm{R}^{2}=0.6938 \quad * * *\end{array}$ \\
\hline Rice straw & $\begin{array}{l}\Delta \mathrm{T}_{40}=0.03571 \mathrm{R}_{\mathrm{n}}-2.3782 \\
\mathrm{R}^{2}=0.7041 \quad * * * \\
\Delta \mathrm{T}_{80}=0.0261 \mathrm{R}_{\mathrm{n}}-2.0171 \\
\mathrm{R}^{2}=0.6092 \quad * *\end{array}$ & $\begin{array}{l}\Delta \mathrm{T}_{40}=0.0244 \mathrm{R}_{\mathrm{n}}-4.353 \\
\mathrm{R}^{2}=0.7635 \\
\Delta \mathrm{T}_{80}=-0.0112 \mathrm{R}_{\mathrm{n}}+8.2379 \\
\mathrm{R}^{2}=0.6266 \quad * *\end{array}$ \\
\hline Wet soil & $\begin{array}{l}\Delta \mathrm{T}_{40,80}=0.01234 \mathrm{R}_{\mathrm{n}}-8.208 \\
\mathrm{R}^{2}=0.50\end{array}$ & $\begin{array}{l}\Delta \mathrm{T}_{40,80}=0.0127 \mathrm{R}_{\mathrm{n}}-8.556 \\
\mathrm{R}^{2}=0.815\end{array}$ \\
\hline
\end{tabular}

rice straw as a mulching material at the same treatment when using $80 \mathrm{~cm}$ bed width line. This may revealed to wind effect in this day or moisture content in soil at the measurement time. The significance of regression equations appeared a significant between solar radiation and differences temperature upper and lower mulch element in all treatments. The degree of significant differs between the treatments.

After irrigation treatment gave the higher significant more than before irrigation and in between irrigation. The previous result refer to the 
thermal properties of water is higher than the air this cause that wet bare soil gave more heating than dry bare soil.

The high significant of black mulch material refer to the black body properties which can absorb most of solar radiation flux incident on it's surface. Also, the significant white plastic as a mulch element equal or increase compare with black plastic sheet as a mulch element, because the white sheet represents a translucent materials which can prevented the long wave to escape from the mulch element. This phenomena named as greenhouse effect which occurred when the short wavelength heat radiation from the sun (has too high temperature) is transmitted by the glass (translucent material) into the inside and absorbed by plants, soil and other objects in the greenhouse. These objects induce a rise in temperature, but since their temperature is not very high, they emit radiation of long wavelength. These cannot pass through the glass cover, and is reflected and retained in the greenhouse (mulch element) including the thermal trapping

The soil moisture content before, after and in between irrigation under different mulching material using two categories $0.40 \mathrm{~m}$ (half- mulching) and $0.80 \mathrm{~m}$ (full mulching) as shown Table (6). The black plastic gave higher value with $80 \mathrm{~cm}$ width line for the soil moisture content after irrigation while bare soil gave lower value for the soil moisture content after irrigation.

Table(6): Soil moisturecontent, \% under different mulching material

\begin{tabular}{|c|c|c|c|c|c|c|c|}
\hline TREATMENT & BS & $\mathbf{C P}_{40}$ & $\mathbf{C P}_{80}$ & $\mathbf{B P}_{40}$ & $\mathbf{B P}_{80}$ & $\mathbf{R S}_{40}$ & $\mathbf{R S} \mathbf{s o}_{80}$ \\
\hline Before irrigation & 22.13 & 29.07 & 30.60 & 30.50 & 33.37 & 31.27 & 31.54 \\
\hline After irrigation & 31.05 & 31.86 & 32.21 & 31.90 & 37.66 & 32.60 & 32.31 \\
\hline $\begin{array}{l}\text { In between } \\
\text { irrigation }\end{array}$ & 26.01 & 27.82 & 28.70 & 26.60 & 30.81 & 27.85 & 26.80 \\
\hline
\end{tabular}

CP: colorless plastic mulching sheet, BP: black plastic mulching sheet, RS: rice straw mulching material, BS: bare soil; 
The cowpea characteristics during the growth period such as plant height, No. of branches, No. of leaves, leaf index area and yield crop in harvesting time as shown Table (7). The values in mulching treatments were higher than control treatment except plant height gave higher value equal rice straw mulch with $80 \mathrm{~cm}$ width line. In addition, the rice straw as a mulching material gave higher values compared with other treatments.

\section{CONCLUSION}

Solar radiation flux incident on mulch surface have a significant effect on heating soil. The relationship between solar radiation and heating soil depend upon color of mulching material surface. The present study revealed that rice straw can be use as a mulching materials to heat of soil, although, inorganic mulching materials gave Table (7): Fresh yield characteristics under different mulching material

\begin{tabular}{||c|c|c|c|c|c|c|c||}
\hline $\begin{array}{c}\text { MULCHING } \\
\text { MATERIAL }\end{array}$ & $\mathrm{CP}_{40}$ & $\mathrm{CP}_{80}$ & $\mathrm{BP}_{40}$ & $\mathrm{BP}_{80}$ & $\mathrm{RS}_{40}$ & $\mathrm{RS}_{80}$ & $\mathrm{BS}$ \\
\hline Plant height, cm & 51.40 & 53.03 & 48.13 & 46.43 & 52.87 & 53.55 & 53.55 \\
\hline No. of branches & 4.83 & 4.93 & 4.73 & 4.87 & 5.03 & 5.17 & 4.13 \\
\hline No. of leaves & 17.90 & 17.93 & 17.80 & 17.90 & 18.03 & 18.13 & 17.40 \\
\hline $\begin{array}{c}\text { Leaf index area, } \\
\text { cm }^{2}\end{array}$ & 136.67 & 136.67 & 134.67 & 136.67 & 136.00 & 138.00 & 127.33 \\
\hline \begin{tabular}{c} 
Yield crop, t/fed \\
\hline
\end{tabular} & 1.17 & 1.17 & 1.16 & 1.17 & 1.18 & 1.17 & 1.16 \\
\hline
\end{tabular}

CP: colorless plastic mulching sheet, BP: black plastic mulching sheet, RS: rice straw mulching material, BS: bare soil;

heating values of soil more than rice straw. The experiments showed that the heating of soil after irrigation had height values more than before and in between irrigation. Ultimately, using mulch with irrigation improvement the soil thermal properties and it has reflected on yield crop. 


\section{REFERENCES}

Adel, M. M. (2002). Man-made climatic changes in the Ganes basin. International Journal of Climattology, 22:993-1016.

Al-Karaghouli, A., A. W. Al- Kayssr and A. M. Hosson. (1990). The photometric properties of different colored plastic mulches used for soil solarization. Solar \& Wind Technology, 7:119-123

ASHRAE HANDBOOK. (2005). Fundamentals: Fenestration. Chapter 31. 1791 TULLIE CIRCL NE, ATLANTA, GA 30329.

Greenough, D. R., L. L. Black and W. P. Bond. (1990). Aluminium surfaced mulch: An approach to the control of tomato spotted wilt virus in solanaceous crops. Plant Dis, 74:805-808.

Ham, J. M., G. J. Kluitenberg and W. J. Lamont. (1993). Optical properties of plastic mulches affect the field temperature regime. J. Amer. Soc. Hort. Sci, 118: 88-193.

Horowitz, M., Y. R. Regev and G. Herzlinger. (1983). Solarization for weed control. Weed Sci, 9: 31:170.

Kluitenberg, G. J., J. M. Ham, and W. J. Lamont. (1991). Effects of aging on the optical properties of plastic mulches. Proc. Natl. Agr. Plastic Congress, 23: 149-154.

Kar, G. (2003)."Tuber yield of potato as influenced by planting dates and mulches". J. Agrometerol. 5: 60-67

Rong Li., Xianqing Houa., Zhikuan Jia., Qingfang Han., Xiaolong Ren and Baoping Yang. (2013). Effects on soil temperature, moisture, and maize yield of cultivation with ridge and furrow mulching in the rainfed area of the Loess Plateau, China. Agricultural Water Management, 116:101-109.

Lamont, W. J. (1993). Plastic mulches for the production of vegetable crops. Hort. Technology, 3: 35-39. 
Novak, M. D., W. Chen and M. A. Hares. (2000). Simulating the radiation distribution within a barely-straw mulch. Agriculture and Forest Meteorology, 102: 173-186.

Singh , R., S., R. R. Sharma, and R. R. Goyal (2007). interacting effects of planting time and mulching on "chandeler" strawberry ( Fargaria $\times$ ananass Duch). Sci. Hort, 111: 344-351.

Tarara, J. M. (2000). Microclimate modification with plastic mulch. HortScience, 35:169-180.

Unger, P. W. (Ed.). (1994). Managing agriculture residues. Lewis publishers, Boca Raton, FL. 448 pp.

$$
\text { الملخص العربى }
$$

تاثير الاشعاع الثمسى ومواد التغطية على تسخين التربة الجافة والرطبة

$$
\text { أسعد درباله }
$$

يعتبر تسخين التربة بإستخدام مو اد تغطية التربة ذو فو ائد متعددة منها: تدفئة التربـة ، تقليل نشـاط

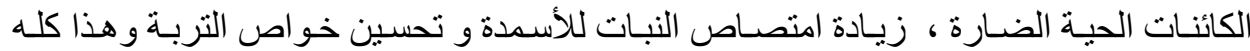

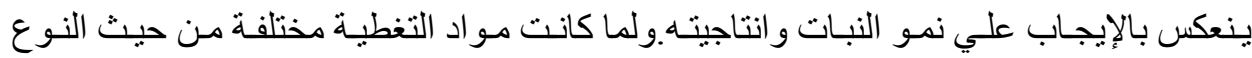

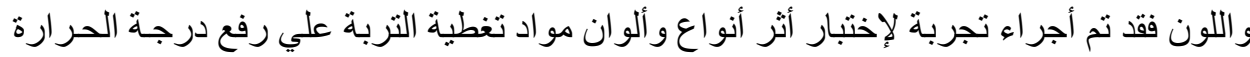

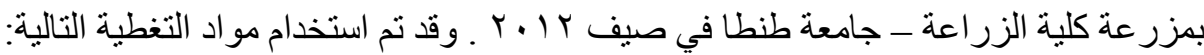

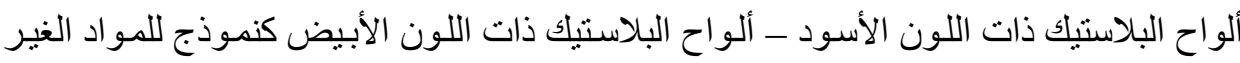

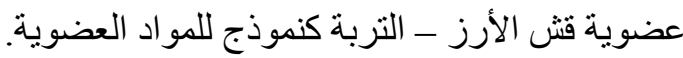

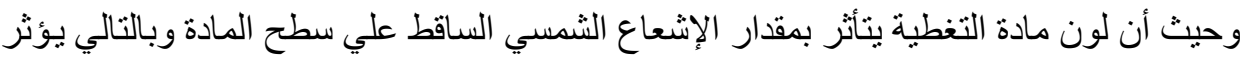
في مدي تسخين التربة.

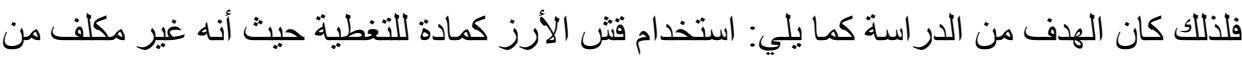

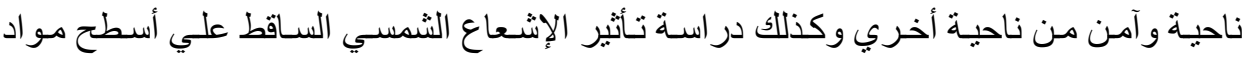
التغطية وقد تم استخدام الري السطحي و تقسيم التجربـة إلـي قطع تجريبيـة تحت ثنلاث مستويات للري

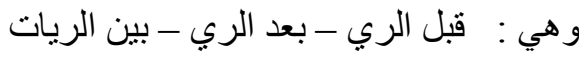
كذلك تم استخدام فروق درجات الحر ارة بين السطح العلوي والسطح السفلي لمادة التغطية ودرجة

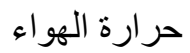

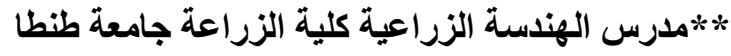




\section{وقد أظهرت النتائج ما يلي:}

- إمكانية إستخدام قش الأرز كمادة لتغطية التربة ، حيث أن فروق درجات الحرارة تحت

$$
\text { ظروف هذه التجربة كانت معنوية }
$$

- وجود تأثير معنوي للإشعاع الثمسي علي تسخين التربة

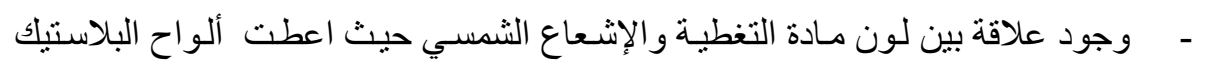

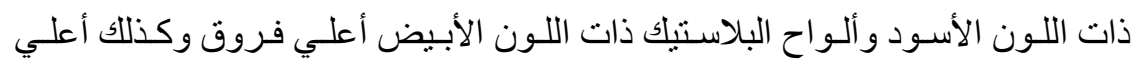
درجات معنوية وذلك في معاملات بعد الري وبين الريات دات الاتون

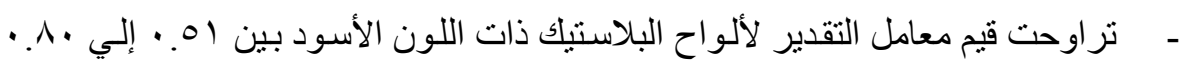

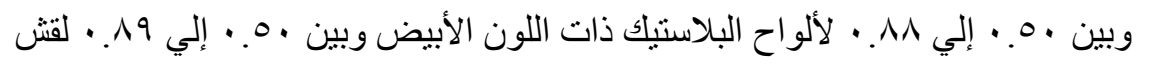

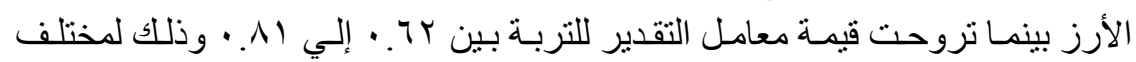

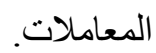

